\title{
The 5-aromatic hydantoin-3-acetate derivatives as inhibitors of the tumour multidrug resistance efflux pump P-glycoprotein (ABCB1): Synthesis, crystallographic and biological studies
}

\author{
Ewa Żesławska ${ }^{\mathrm{a}, *}$, Annamária Kincses ${ }^{\mathrm{b}}$, Gabriella Spengler ${ }^{\mathrm{b}}$, Wojciech Nitek ${ }^{\mathrm{c}}$, Karolina Wyrzuc ${ }^{\mathrm{d}}$, \\ Katarzyna Kieć-Kononowicz ${ }^{\mathrm{d}}$, Jadwiga Handzlik ${ }^{\mathrm{d}, *}$ \\ a Department of Chemistry, Institute of Biology, Pedagogical University of Cracow, ul. Podchorązych 2, 30-084 Kraków, Poland \\ ${ }^{\mathrm{b}}$ Department of Medical Microbiology and Immunobiology, Faculty of Medicine, University of Szeged, Szeged, Hungary \\ ${ }^{\mathrm{c}}$ Faculty of Chemistry, Jagiellonian University, ul. Ingardena 3, 30-060 Kraków, Poland \\ ${ }^{\mathrm{d}}$ Department of Technology and Biotechnology of Drugs, Jagiellonian University Medical College, Medyczna 9, 30-688 Kraków, Poland
}

\section{A R T I C L E I N F O}

\section{Article history:}

Received 5 February 2016

Revised 14 April 2016

Accepted 25 April 2016

Available online 26 April 2016

\section{Keywords:}

Derivatives of hydantoin

Multidrug resistance inhibitors

Crystal structure

P-glycoprotein (ABCB1)

\begin{abstract}
A B S T R A C T
A series of arylpiperazine derivatives of hydantoin-3-acetate, including previously obtained 5,5-diphenylhydantoin (1-7) and new-synthesized spirofluorene-hydantoin derivatives (8-12), were investigated in the search for new inhibitors of the tumour multidrug resistance (MDR) efflux pump P-glycoprotein (P-gp, ABCB1) overexpressed in mouse T-lymphoma cells. Synthesis of new compounds (8-12) was performed. Crystal structures of two compounds (8 and 11) were determined by X-ray diffraction method. The conformations of the investigated molecules ( $\mathbf{8}$ and $\mathbf{1 1})$ in the crystalline samples are different. The bent conformation seems to be more favourable for biological activity than the extended one. The efflux pump inhibitory properties of the compounds 1-12 were evaluated in the fluorescence uptake assay using rhodamine 123 dye in mouse T-lymphoma model in vitro. Their cytotoxic action was examined, too. All compounds with methyl acetate moiety displayed high potency to inhibit the MDR efflux pump. The most active compound, methyl 2-(1-(4-(4-(2,3-dichlorophenyl)piperazin-1-yl) butyl)-5,5-diphenylhydantoin-3-yl)acetate (5), tested at 1/10 of verapamil concentration displayed the 9-fold higher P-gp inhibitory action.
\end{abstract}

(c) 2016 Elsevier Ltd. All rights reserved.

\section{Introduction}

Multidrug resistance (MDR) has become a factor seriously limiting the treatment of various diseases, particularly anticancer treatment. ${ }^{1-5}$ The major reason for failure of chemotherapy of cancer is the refractory nature of the cells that results from prior exposure to the same or other chemotherapeutic agents. In most of the tumour cell lines, multidrug resistance is often associated with cellular overexpression of the members of the ATP-binding cassette (ABC) transporter family, such as P-glycoprotein (P-gp or ABCB1), which acts as an efflux pump for various anticancer drugs. P-gp is encoded by the MDR1 ( $A B C B 1$ ) gene and its overexpression in cancer cells has become a therapeutic target to combat multidrug resistance. ${ }^{1}$ Consequently, it is a major challenge for medicinal science to find a successful method to inhibit P-gp function during chemotherapy. A main strategy to circumvent the tumour MDR is

\footnotetext{
* Corresponding authors. Tel.: +48 126627882 (E.Ż.), +48 126205584 (J.H.).

E-mail addresses: zeslawsk@up.krakow.pl (E. Żesławska), j.handzlik@uj.edu.pl (J. Handzlik)
}

to co-administer efflux pump inhibitors (EPIs), namely compounds which are able to block efflux action of MDR drug transporters. ${ }^{1-5}$ Another challenge is to identify an architecture-mechanism relationship for the ABC-drug transporters, especially for P-gp. Thus, discovery and structural analysis of small molecules being modulators of this transport protein play a significant role in comprehensive studies on cancer MDR.

Lines of evidence indicate a number of chemical compounds that modulate P-gp in various assays conditions. Predominantly, three generations of MDR reversal agents have been widely investigated. ${ }^{1,3-7}$ The results obtained 'are not encouraging' ${ }^{1}$ and it suggests that a further search for MDR reversal agents with higher activity and better pharmacological profile are desirable.

On the other hand, derivatives of hydantoin seem to be an interesting lead in pharmacological strategies for overcoming multidrug resistance. Recent studies distinctly identified and described a presence of benzyl-hydantoin binding site in protein transporters (nucleobase-cation-symport-1 transporters, Mhp, from Microbacterium liquefaciens). ${ }^{8,9}$ Furthermore, several reports have underlined hydantoins' anticancer properties, i.e., an anti-metastatic 


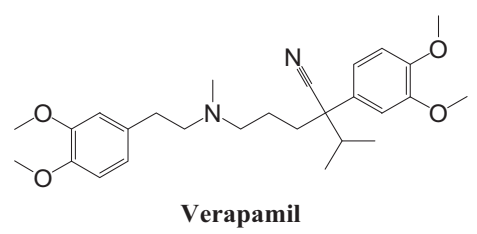

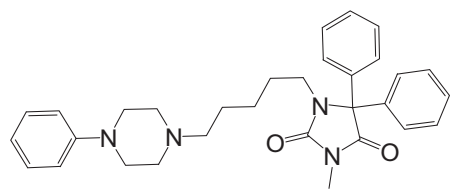

BS-1

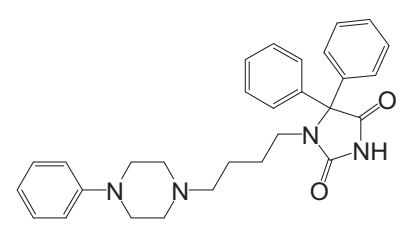

JH-63

Figure 1. Verapamil and the most potent hydantoin P-gp modulators, BS-1 and JH-63, identified within previous studies. ${ }^{11,12}$

Table 1

Chemical structures of compounds 1-12

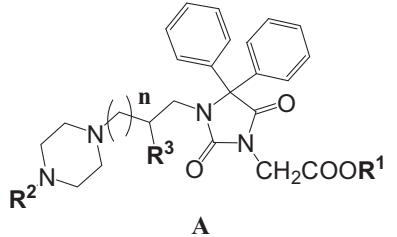

A

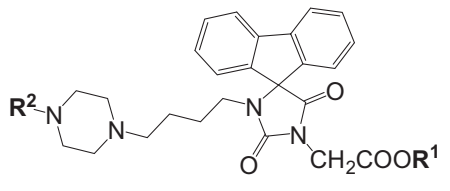

B

\begin{tabular}{|c|c|c|c|c|c|}
\hline Compound & Structure & $\mathrm{R}^{1}$ & $\mathrm{R}^{2}$ & $\mathrm{R}^{3}$ & $n$ \\
\hline 1 & A & Me & $\mathrm{Ph}$ & $\mathrm{OH}$ & 1 \\
\hline 2 & A & Me & $\mathrm{Ph}$ & $\mathrm{H}$ & 1 \\
\hline 3 & A & Me & $\mathrm{Ph}$ & $\mathrm{H}$ & 2 \\
\hline 4 & A & Me & 2-F-Ph & $\mathrm{H}$ & 2 \\
\hline 5 & A & Me & 2,3-DiCl-Ph & $\mathrm{H}$ & 2 \\
\hline 6 & A & $\mathrm{H}$ & 2-MeO-Ph & $\mathrm{OH}$ & 1 \\
\hline 7 & A & $\mathrm{H}$ & 2-MeO-Ph & $\mathrm{H}$ & 2 \\
\hline 8 & B & Me & 2-Furoyl & - & - \\
\hline 9 & B & $\mathrm{H}$ & 2-Furoyl & - & - \\
\hline 10 & B & Me & 4-F-Ph & - & - \\
\hline 11 & B & Me & $\mathrm{Ph}$ & - & - \\
\hline 12 & B & Me & 2-F-Ph & - & - \\
\hline
\end{tabular}

activity for phenylmethylene-hydantoins. ${ }^{10}$ Thus in the previous studies, ${ }^{11-14}$ a series of our representative aromatic (thio)hydantoin derivatives were evaluated on their P-glycoprotein inhibition properties in $A B C B 1$-transfected mouse lymphoma or colon adenocarcinoma cells using accumulation assay and/or real-time fluorometry with two dye substrates of $A B C B 1$; a rhodamine 123 and/or ethidium bromide. ${ }^{15}$ Most of the compounds inhibited the $A B C B 1-m e d i a t e d ~ e f f l u x$, particularly, phenylpiperazine derivatives of 5,5-diphenylhydantoin that contain methyl-substituted (BS-1) or unsubstituted (JH-63) position 3 (Fig. 1) showed inhibition potency much higher than that of verapamil, a reference P-gp modulator, ${ }^{11,12}$ whereas the 5,5-dimethylhydantoins with aromatic substituent at position 3 or 5-arylidenoimidazolones demonstrated much weaker impact on this MDR efflux pump, in the range of verapamil at most. ${ }^{13,14}$ Interestingly, there was almost no difference in very strong P-gp inhibitory action of phenylpiperazine-5,5diphenylhydantoins with $\mathrm{H}$ or Me at position 3, whereas a shift of beneficial aromatic moieties from position 5 to position 3 significantly decreased the action. This suggested a hypothesis that the position 3 may not contribute in the P-gp binding whatever is substituted there.

Taking this into account, we decided to modify the previously active phenylpiperazine hydantoin structures (BS-1, JH-63) by introduction of an end-ester group to a substituent at position 3, and varied arylpiperazine-alkyl fragments at position 1 of hydantoin (1-5, Table 1). Additionally, two compounds with not recommended carboxylic acid end at position 3 ( 6 and 7 , Table 1 ) were examined to evaluate the contribution of the position 3 in the P-gp binding. In the next step of the modifications, two phenyl rings of the 5,5-diphenylhydantoin were bridged to give spirofluorene-hydantoin derivatives (8-12, Table 1$)$. Here, synthesis and crystallographic studies for selected compounds as well as biological evaluation for the entire series (1-12) are described. The structure-activity relationship has been discussed, too.

\section{Results and discussion}

\subsection{Chemistry}

Syntheses of compounds 1-7 were described elsewhere. ${ }^{15-17}$ The synthetic route of arylpiperazine derivatives 8-12 was carried out according to the Scheme 1 . Starting from commercially available 9-fluorenone, Bucherer-Bergs reaction was achieved by the use of ammonium carbonate and potassium cyanide to afford the spirofluorene-hydantoin, compound 13. In the following steps, $\mathrm{N}$ alkylation at position 3 of hydantoin with methyl bromoacetate (14) and $N$-alkylation at position 1 (15) with 1,4-dibromobutane were carried out. The fourth stage was the $N$-alkylation of an appropriate arylpiperazine. The compound $\mathbf{9}$ with the carboxylic acid terminal fragment was obtained in the last step of the synthesis by hydrolysis of the ester (8) in the presence of potassium hydroxide (Scheme 1).

\subsection{Crystallographic studies}

In all studied compounds, the main difference in conformation of molecules seems to be dependent on the flexible aliphatic chain which connects the hydantoin and piperazine rings. The conformations of two derivatives $\mathbf{8}$ (hydrochloride) and $\mathbf{1 1}$ (base) were analysed by determination of the crystal structures using X-ray diffraction method. 


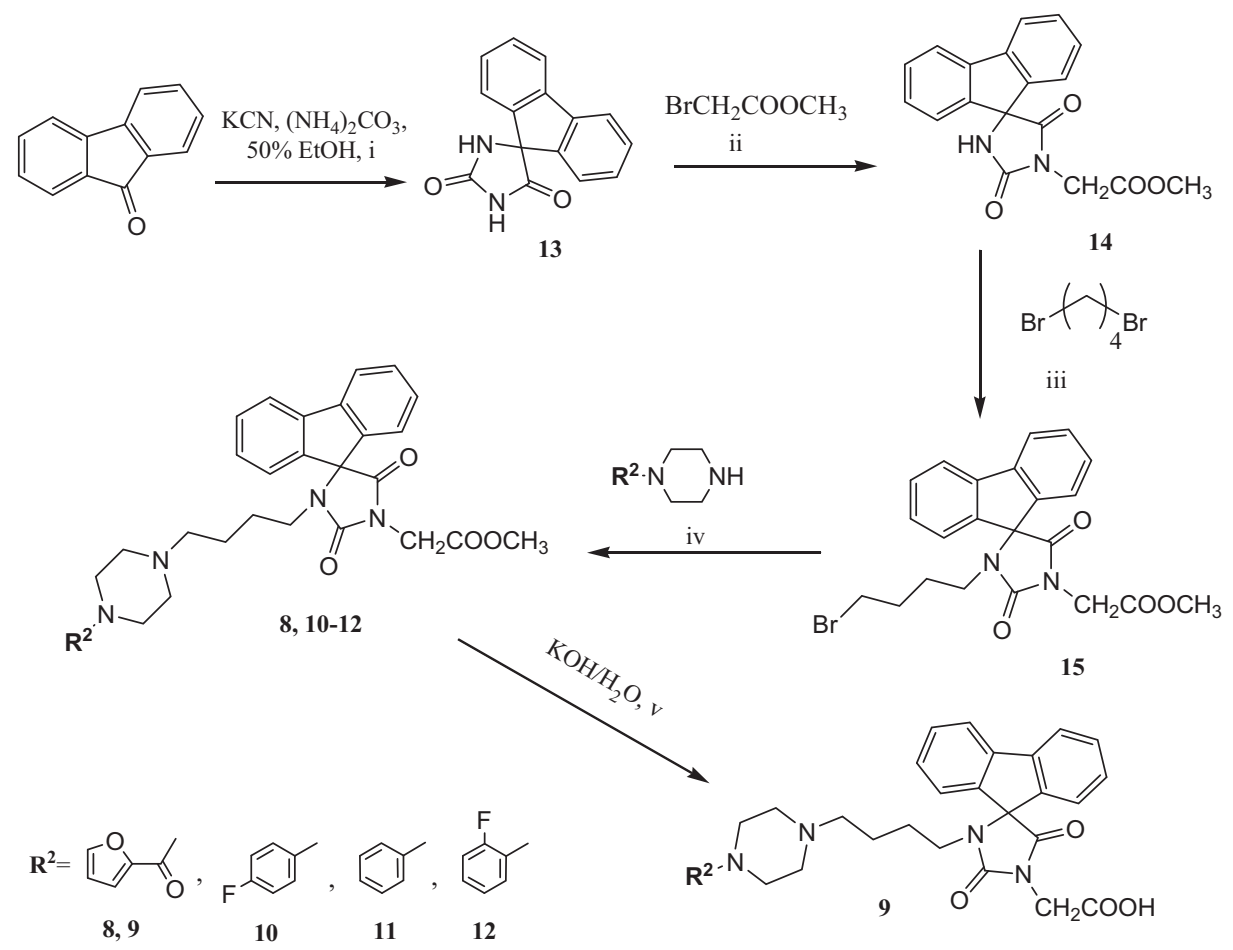

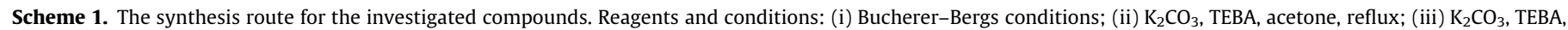
acetone, rt; (iv) $\mathrm{K}_{2} \mathrm{CO}_{3}$, acetone, reflux; (v) $2 \mathrm{~h}$, rt.

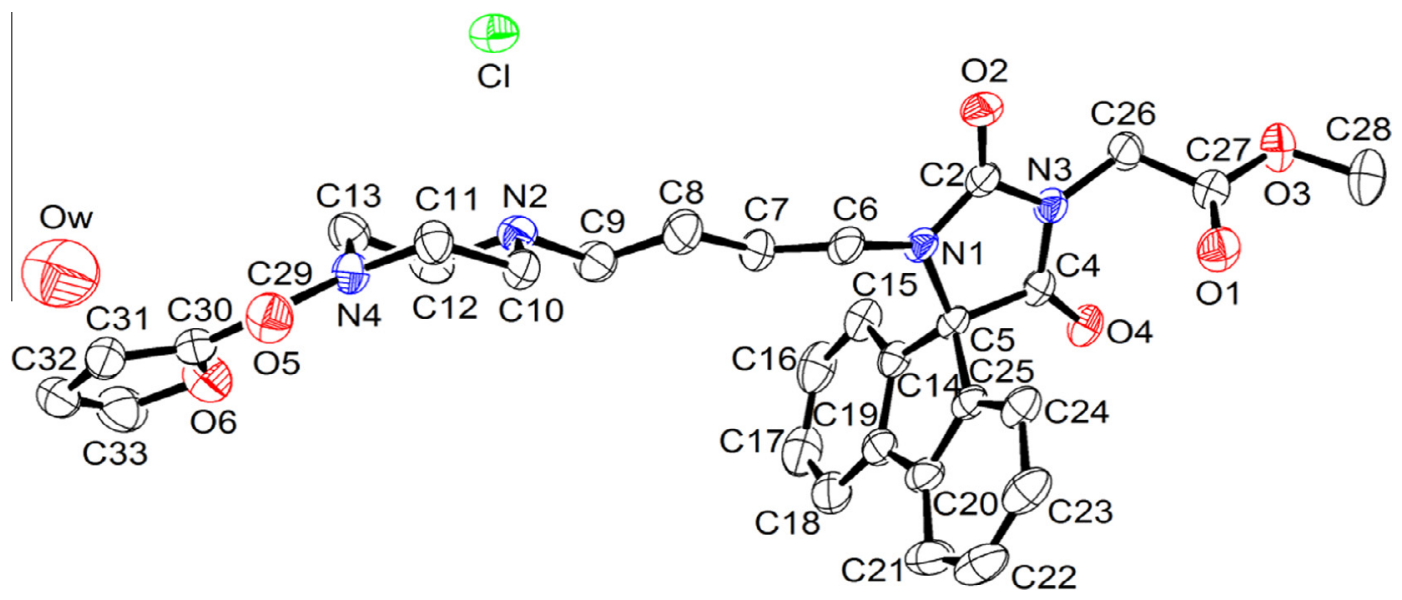

Figure 2. Atom numbering scheme of $\mathbf{8}$. Displacement ellipsoids are drawn at the $30 \%$ probability level. Hydrogen atoms have been omitted for clarity.

The atom numbering scheme of the $\mathbf{8}$ is given in Figure 2. The unit cell consists of four molecules. The conformation of $\mathbf{8}$ is extended. The molecule is protonated (at N2) by the proton transfer from $\mathrm{HCl}$ and makes hydrogen bond with chlorine anion.

The data for the hydrogen bonds are collected in Table 2. The spirofluorene substituent is almost perpendicular to hydantoin

Table 2

Parameters of intermolecular interactions for $\mathbf{8}$

\begin{tabular}{|c|c|c|c|c|}
\hline & $\mathrm{H} \cdots \mathrm{A}(\AA)$ & $\mathrm{D} \cdots \mathrm{A}(\AA)$ & $\mathrm{D}-\mathrm{H}-\mathrm{A}\left({ }^{\circ}\right)$ & Symmetry code \\
\hline $\mathrm{N} 2-\mathrm{H} 2 \mathrm{~N} \cdots \mathrm{Cl}$ & $2.12(4)$ & $3.049(3)$ & $163(3)$ & \\
\hline OW-HWA $\cdots$ O5 & 2.20 & $3.046(6)$ & 179.7 & \\
\hline $\mathrm{OW}-\mathrm{HWB} \cdots \mathrm{Cl}$ & 2.25 & $3.102(5)$ & 179.6 & $x+1 / 2,-y+1 / 2, z+1 / 2$ \\
\hline C26-H26A …WW & 2.45 & $3.255(6)$ & 140.1 & $-x,-y+1,-z+2$ \\
\hline C31-H31…W & 2.12 & $3.005(6)$ & 158.9 & \\
\hline $\mathrm{C} 8-\mathrm{H} 8 \mathrm{~A} \cdots \mathrm{Cl}$ & 2.64 & $3.492(5)$ & 151.9 & $-x,-y,-z+2$ \\
\hline
\end{tabular}

ring. The angle between the planes of these moieties is $86.7^{\circ}$. The carbonyl groups of hydantoin ring and the oxygen atoms of the ester group are not involved in any hydrogen bonds.

Only one oxygen atom of furoyl group at piperazine ring is engaged in intermolecular hydrogen bonds (Fig. 3). Furthermore, a water molecule is involved in hydrogen bonds with the molecules of 8.

The unit cell of $\mathbf{1 1}$ consists of four molecules. The molecular geometry with the atom numbering scheme is shown in Figure 4.

The conformation of molecule is bent in comparison to $\mathbf{8}$, its shape without spirofluorene substituent reminds a hairpin. This difference can be illustrated by the values of torsion angle N1C6-C7-C8 $-169.2^{\circ}$ and $-54.5^{\circ}$ for 8 and 11, respectively. The spirofluorene substituent is perpendicular to hydantoin ring with the interplanar bond angle $89.7^{\circ}$. In the crystal net, this substituent is engaged in $\pi-\pi$ interactions (Fig. 5 ). The distance between the 


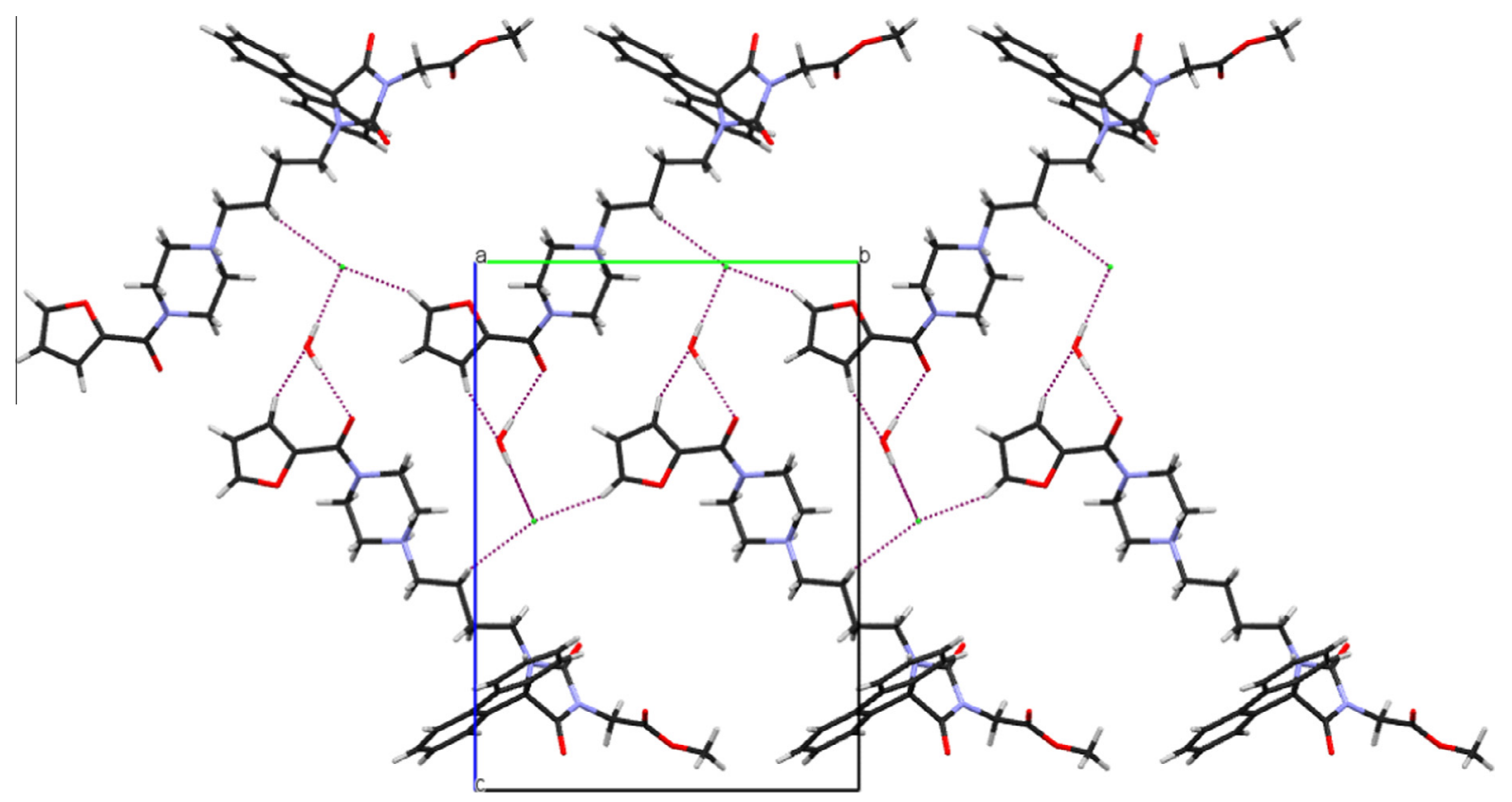

Figure 3. Partial packing view along [100] direction for 8. Dashed lines indicate hydrogen bonds.

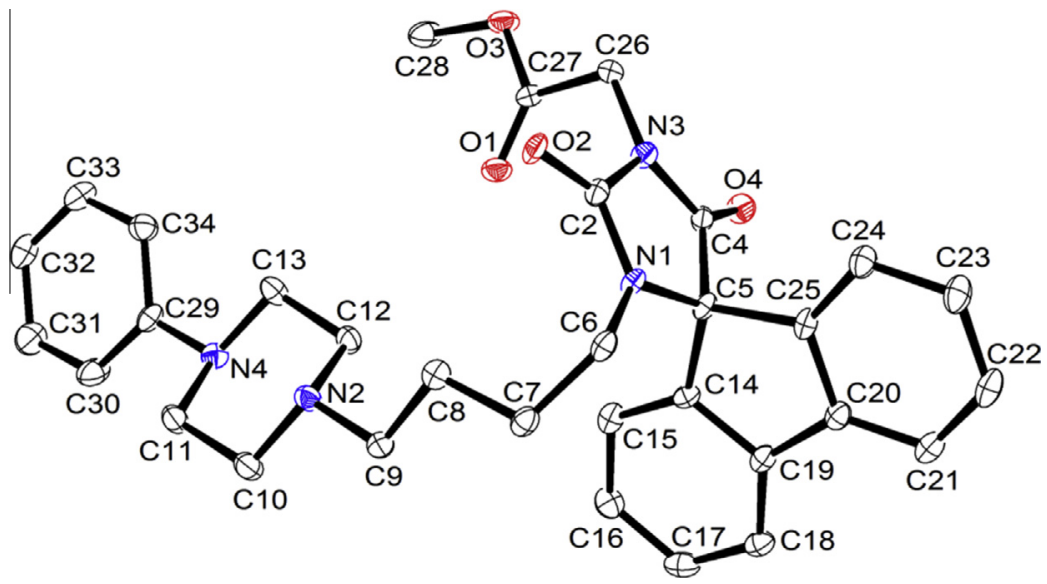

Figure 4. Atom numbering scheme of 11. Displacement ellipsoids are drawn at the 30\% probability level. Hydrogen atoms have been omitted for clarity.

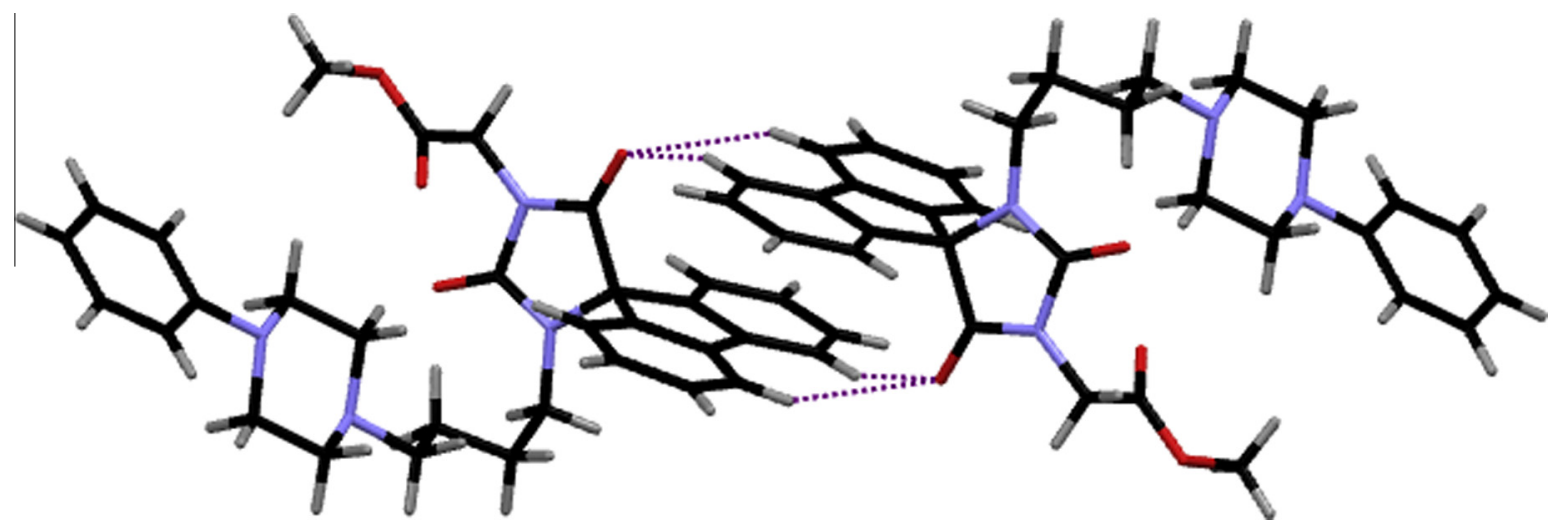

Figure 5. The interaction of two molecules of $\mathbf{1 1}$ showing a $\pi-\pi$ stacking. Dashed lines indicate hydrogen bonds.

planes of spirofluorene substituents is $3.45 \AA$. In this conformation all oxygen atoms are involved in intermolecular $\mathrm{C}-\mathrm{H} \cdots \mathrm{O}$ contacts, which parameters are summarized in Table 3. Nitrogen atoms are not engaged in intermolecular interactions. 
Table 3

Parameters of $\mathrm{C}-\mathrm{H} \cdots \mathrm{O}$ interactions for $\mathbf{1 1}$

\begin{tabular}{lllll}
\hline & $\mathrm{H} \cdots \mathrm{A}(\AA)$ & $\mathrm{D} \cdots \mathrm{A}(\AA)$ & $\mathrm{D}-\mathrm{H}-\mathrm{A}\left({ }^{\circ}\right)$ & Symmetry code \\
\hline $\mathrm{C} 6-\mathrm{H} 6 \mathrm{~A} \cdots \mathrm{O} 1$ & 2.45 & $3.390(2)$ & 159.4 & $x,-y+5 / 2, z+1 / 2$ \\
$\mathrm{C} 12-\mathrm{H} 12 \mathrm{~B} \cdots \mathrm{O} 1$ & 2.47 & $3.306(2)$ & 141.3 & \\
$\mathrm{C} 13-\mathrm{H} 13 \mathrm{~B} \cdots \mathrm{O} 2$ & 2.44 & $3.400(2)$ & 162.6 & $x,-y+5 / 2, z-1 / 2$ \\
$\mathrm{C} 18-\mathrm{H} 18 \cdots \mathrm{O} 4$ & 2.69 & $3.558(2)$ & 152.0 & $-x,-y+2,-z$ \\
$\mathrm{C} 21-\mathrm{H} 21 \cdots 04$ & 2.69 & $3.555(9)$ & 151.8 & $-x,-y+2,-z$ \\
$\mathrm{C} 28-\mathrm{H} 28 \mathrm{C} \cdots \mathrm{O} 3$ & 2.58 & $3.298(2)$ & 133.8 & $-x+1,-y+2,-z$ \\
$\mathrm{C} 28-\mathrm{H} 28 \mathrm{C} \cdots \mathrm{O} 2$ & 2.46 & $3.298(2)$ & 133.8 & $x,-y+5 / 2, z-1 / 2$ \\
\hline
\end{tabular}

\subsection{Biological assays}

\subsubsection{Efflux modulating effects}

The hydantoin derivatives 1-12 (Table 1 ) were evaluated for their efflux modulating effects in cancer cells (mouse T-lymphoma cell line transfected with the human MDR1 (ABCB1) gene that codes for the $A B C$ transporter $A B C B 1$ ) using a rhodamine 123 accumulation assays. ${ }^{11,18,19}$ Rhodamine 123 is the substrate for $A B C B 1$. The percentage of mean fluorescence intensity was calculated for the treated MDR cells as compared with the untreated cells. A fluorescence activity ratio (FAR) was calculated based on the equation described in the experimental section. All compounds were investigated at the concentration of $20 \mu \mathrm{M}$ verapamil and at the 10 -fold lower concentration $(2 \mu \mathrm{M})$. Both, ester and carboxylic acid, compounds investigated (1-12) were stable under the biological assays conditions. Results are shown in the Table 4. Among the hydantoin derivatives evaluated for their inhibition action on the $A B C B 1$ transporter, the compounds 1-5 and 10-12 were much more effective than the reference inhibitor verapamil, compound $\mathbf{8}$ displayed activities in the range of verapamil and the action of compounds $\mathbf{6}$, $\mathbf{7}$ and $\mathbf{9}$ were significantly lower. Two very active compounds (4 and 5) showed an activity-concentration inversion in the fluorescence assay, giving higher FAR value at the lower concentration $(2 \mu \mathrm{M})$ with a slight decrease at the higher one (Table 4).

\subsubsection{Cytotoxic effects}

Compounds were also examined for their cytotoxic action in both, sensitive (PAR) and resistant (MDR) mouse T-lymphoma cell lines (Table 5).

The tested hydantoins 1-12 showed low or very low cytotoxic effects in both cell lines. Especially, compounds 2, 4, 6, 9 and 11 displayed no cytotoxicity in the MDR cell line up the concentration of $100 \mu \mathrm{M}$. The cytotoxic concentration of all compounds (1-12)

\section{Table 4}

Effects of compounds 1-12 on rhodamine 123 retention by human MDR1 (ABCB1) gene-transfected mouse lymphoma cells

\begin{tabular}{lll}
\hline Compounds & FAR (concentration of $2 \mu \mathrm{M})$ & FAR (concentration of $20 \mu \mathrm{M})$ \\
\hline Verapamil & - & 17.59 \\
DMSO $(2 \mathrm{v} / \mathrm{v} \%)$ & 0.84 & - \\
$\mathbf{1}$ & 72.64 & 90.43 \\
$\mathbf{2}$ & 89.34 & 116.27 \\
$\mathbf{3}$ & 77.15 & 99.82 \\
$\mathbf{4}$ & 102.74 & 99.09 \\
$\mathbf{5}$ & 132.85 & 98.11 \\
$\mathbf{6}$ & 0.84 & 0.86 \\
$\mathbf{7}$ & 1.00 & 2.04 \\
$\mathbf{8}$ & 1.86 & 24.89 \\
$\mathbf{9}$ & 0.68 & 0.69 \\
$\mathbf{1 0}$ & 19.40 & 71.11 \\
$\mathbf{1 1}$ & 21.61 & 70.19 \\
$\mathbf{1 2}$ & 35.38 & 72.04
\end{tabular}

FAR, fluorescence activity ratio, was calculated using the following equation: $\mathrm{FAR}=\frac{\mathrm{MDR}_{\text {treated }} / \mathrm{MDR}_{\text {control }}}{\text { parental }}$

The inhibition of ABCB1 transporter is evident when FAR $>1 .{ }^{11}$ Since the treatment had no effect on the parental cells (PAR) lacking the overexpressed ABCB1 system, the intensity of fluorescence did not change in the treated cells compared to the control ones, for this reason the denominator was considered as 1 .
Table 5

Cytotoxic effect of the compounds on sensitive parental (PAR) and resistant (MDR) mouse T-lymphoma cells

\begin{tabular}{lll}
\hline Compound & PAR Mean $(\mu \mathrm{M}) \pm$ SD & MDR Mean $(\mu \mathrm{M}) \pm$ SD \\
\hline $\mathbf{1}$ & $33 \pm 3$ & $67 \pm 8$ \\
$\mathbf{2}$ & $40 \pm 3$ & $>100$ \\
$\mathbf{3}$ & $13 \pm 1$ & $26 \pm 2$ \\
$\mathbf{4}$ & $>100$ & $>100$ \\
$\mathbf{5}$ & $18 \pm 3$ & $40 \pm 6$ \\
$\mathbf{6}$ & $>100$ & $>100$ \\
$\mathbf{7}$ & $>100$ & $>100$ \\
$\mathbf{8}$ & $59 \pm 13$ & $63 \pm 9$ \\
$\mathbf{9}$ & $>100$ & $>100$ \\
$\mathbf{1 0}$ & $40 \pm 6$ & $56 \pm 14$ \\
$\mathbf{1 1}$ & $53 \pm 5$ & $>100$ \\
$\mathbf{1 2}$ & $58 \pm 6$ & $84 \pm 2$ \\
\hline
\end{tabular}

was much higher than their lower concentration $(2 \mu \mathrm{M})$ in the rhodamine 123 accumulation assay. Only two compounds, $\mathbf{3}$ and $\mathbf{5}$, demonstrated cytotoxic properties in the range of the higher concentration $(20 \mu \mathrm{M})$ in the accumulation assay (Tables 4 and 5). The relatively higher cytotoxic action in the PAR cells than that of cell lines with overexpression of $\mathrm{ABCB} 1$ was found for all compounds that were very potent in the accumulation assays $(\mathbf{1}-\mathbf{3}, \mathbf{5}$, 10-12), what confirmed the P-gp substrate properties of the compounds (Table 5).

\subsection{Structure-activity relationship discussion}

The obtained results allow us to perform some structureactivity relationship analysis. The highest efflux inhibitory action was found for the 2,3-dichlorophenyl derivative of the ester 5,5-diphenylhydantoin (5), which displayed 9-fold higher FAR value at the lower concentration $(2 \mu \mathrm{M})$ than that of verapamil at the 10 -fold higher concentration $(20 \mu \mathrm{M})$. The very high activity was also observed for the ester 5,5-diphenylhydantoins with 2-fluorophenyl (4) and unsubstituted phenyl at piperazine (2, 3 and 1). Although the spirofluorenehydantoin compounds (8-12) displayed some decrease in the dye efflux inhibitory action in comparison to the corresponding 5,5-diphenylhydantoins (1-7), they represent similar trends in the structure-activity relationship. Thus, all compounds possessing more hydrophobic phenylpiperazine terminal fragment at position 1 of hydantoin and the methyl ester end at position 3 are very potent $A B C B 1$ modulators. The furoyl derivative with ester at position 3 (8) was also an active inhibitor but in the range of verapamil, while it lost the inhibitory potency when the ester group was converted into carboxyl one $(\mathbf{9})$. Likewise, the compounds $\mathbf{6}$ and $\mathbf{7}$ also with the carboxyl terminal fragment had no activity. The examination of the compounds with carboxyl end at position 3 indicates that the N3-side of hydantoin is not hidden from interactions with P-gp. The ester fragment at position 3 is responsible for the high potency (1-5, 10-12), whereas the deprotected acid group (6, 7 and 9) caused a very strong reduction of the inhibitory action. However, our previous results ${ }^{13}$ indicate that introduction of favourable aromatic moieties at 3-hydantoin is not able to maintain the high P-gp inhibitory activities of phenylpiperazine hydantoins when they are deprived of aromatic fragments at position 5 . This suggests that aromatic (phenyl) substituents at position 5 are crucial for the intensive P-gp inhibitory action.

The position of the hydrophobic substituent at the phenylpiperazine phenyl ring seems to be also important as the ortho-fluoro derivative was a bit more beneficial than the para one. Some decrease in activity is noted if the phenylpiperazine phenyl substituent is replaced with the furoyl one (8). However, only an exchange of ester N3-terminal moiety for the aforementioned carboxyl termination (9) significantly reduces the activity. Some role 
of the properties of alkyl linker between piperazine and hydantoin can be seen, as well. The introduction of the hydroxyl group into the linker reduced activity of compounds $\mathbf{1}$ and $\mathbf{6}$ in comparison to the corresponding compounds with unbranched linkers ( 2 and 7). The results indicated that any decrease in hydrophobicity of the 5-aromatic arylpiperazine hydantoin compounds (1-12), observed at both, N3 and N1 terminal fragments, is disadvantageous for the modulating action on $\mathrm{ABCB} 1$.

As far as cytotoxic studies concern, there is no clear structureactivity relationship. In general, the cytotoxic action of the series of hydantoin compounds was rather low, especially in the case of compounds with the carboxylic terminal fragment $(\mathbf{6}, \mathbf{7}$, and 9). However, it is not a rule as the 2-fluorophenylpiperazine ester (4) was also devoid of cytotoxicity in the same concentration range, whereas both structural analogues of the compound $\mathbf{4}$, the phenyl (3) and the 2,3-dichlorophenyl (5) ones, were the most cytotoxic in the whole series.

Crystallographic studies show that the extended conformation of the main motif in investigated molecules is less preferred for better inhibitors of efflux modulating effects in cancer cells (8). Furthermore, this molecule does not use all potential groups, which are able to form hydrogen bonds, to intermolecular interactions. The molecule of $\mathbf{1 1}$ has a bent conformation and more groups are involved in intermolecular hydrogen bonds. This molecule shows much better properties as inhibitor of efflux modulating effects in cancer cells.

\section{Conclusion}

The studies allowed us to identify a new group of very potent Pgp modulators in the cancer cells and to have an insight in their structural properties. On the basis of the results obtained, compounds with ester substituents at position 3 can be considered as very promising cancer MDR efflux pump inhibitors with a potential therapeutic future as their $A B C B 1$ blocking action is much more potent than that of reference modulator, verapamil, and their cytotoxic effects are negligible.

\section{Experimental}

\subsection{Chemical synthesis}

${ }^{1} \mathrm{H}$ NMR spectra were recorded on a Varian Mercury-VX $300 \mathrm{MHz}$ PFG instrument in DMSO- $d_{6}$ at ambient temperature using the solvent signal as an internal standard: the values of the chemical shifts are expressed in $\delta$ values (ppm) and the coupling constants $(J)$ in Hz. Mass spectra were recorded on a UPLC-MS/ MS system consisted of a Waters ACQUITY ${ }^{\circledR}$ UPLC $^{\circledR}$ (Waters Corporation, Milford, MA, USA) coupled to a Waters TQD mass spectrometer (electrospray ionization mode ESI-tandem quadrupole). The UPLC/MS purity of all the final compounds was confirmed to be higher than $95 \%$. Retention times $\left(t_{R}\right)$ are given in minutes. Thinlayer chromatography was performed on pre-coated Merck silica gel $60 \mathrm{~F}_{254}$ aluminium sheets, the used solvent systems were (I) $\mathrm{CH}_{2} \mathrm{Cl}_{2} / \mathrm{MeOH} 19: 1$, (II) toluene/acetone 40:3, (III) toluene/acetone/methanol 15:5:1, (IV) $\mathrm{CHCl}_{3} / i-\mathrm{PrOH} / \mathrm{NH}_{3}$ aq 9:11:3. Melting points were determined using Mel-Temp II apparatus and are uncorrected. The reactions at a fixed temperature were carried out using a magnetic stirrer with a contact thermometer Heidolph MR 2001.

\subsubsection{Synthesis of spiro(fluorene-9,5'-imidazolidin)-2', $4^{\prime}$-dione (13)}

While stirring, a solution of potassium cyanide ( $7.88 \mathrm{~g})$ in water $(160 \mathrm{ml})$ was introduced into a mixture of 9-fluorenone $(18.2 \mathrm{~g}$,
$0.1 \mathrm{~mol}$ ), ammonium carbonate ( $38 \mathrm{~g})$, ethanol $(160 \mathrm{ml})$. The mixture was stirred for $56 \mathrm{~h}$ at $58{ }^{\circ} \mathrm{C}$, according to a progress controlled by TLC (I). After $56 \mathrm{~h}$ the temperature was increased to $88^{\circ} \mathrm{C}$ and the stirring was continued for additional $4 \mathrm{~h}$. The reaction mixture was cooled and acidified with concentrated hydrochloric acid to $\mathrm{pH}$ of 3 . The precipitate was filtered off and crystallized from ethanol to give yellow crystals of 13 . Yield $68 \%$; mp: $304-306{ }^{\circ} \mathrm{C}$; TLC: $R_{f}(\mathrm{I}): 0.32 .{ }^{1} \mathrm{H}$ NMR (DMSO- $\left.d_{6}, \mathrm{ppm}\right) \delta: 7.31-7.39\left(\mathrm{~m}, 2 \mathrm{H}, \mathrm{H}_{2,7}-\mathrm{Ar}\right.$ ), 7.45-7.50 ( $\mathrm{m}, 4 \mathrm{H}, \mathrm{H}_{1,3,6,8}-\mathrm{Ar}$ ), 7.86-7.89 (d def., $2 \mathrm{H}, \mathrm{H}_{4,5}-\mathrm{Ar}$ ), 8.57 (s, $1 \mathrm{H}, \mathrm{H}-\mathrm{N} 1$ ), 11.22 (br s, $1 \mathrm{H}, \mathrm{H}-\mathrm{N} 3$ ). LC-MS: purity $96.73 \%$, $t_{\mathrm{R}}=4.41$, (ESI) $m / z$ : calculated for $\mathrm{C}_{15} \mathrm{H}_{10} \mathrm{~N}_{2} \mathrm{O}_{2}[\mathrm{M}+\mathrm{H}]^{+}: 251.25$ found: 251.08 .

\subsubsection{Synthesis of methyl 2-(spiro(fluorene-9,5'-imidazolidin)-} $2^{\prime}, 4^{\prime}$-dione-3'-yl)acetate (14)

Spiro(fluorene-9,5'-imidazolidine)-2', $4^{\prime}$-dione 13 (0.06 mol, $15 \mathrm{~g})$, potassium carbonate $(24 \mathrm{~g})$, TEBA $(1.8 \mathrm{~g})$ in acetone $(300 \mathrm{ml})$ were stirred under reflux for $30 \mathrm{~min}$. Then a solution of methyl bromoacetate $(0.06$ mole, $9.2 \mathrm{~g})$ in acetone $(60 \mathrm{ml})$ was added and the mixture was maintained at reflux for $6 \mathrm{~h}$, according to a progress controlled by TLC (II). The inorganic precipitate was filtered off. The filtrate, after evaporation of solvents, was crystallized from ethanol to give white crystals of 14. Yield 54\%; mp: 171-173 ${ }^{\circ} \mathrm{C}$; TLC: $R_{f}$ (II): $0.27 .{ }^{1} \mathrm{H}$ NMR (DMSO- $\left.d_{6}, \mathrm{ppm}\right): \delta 3.73$ (s, $\left.3 \mathrm{H}, \mathrm{OCH}_{3}\right), 4.40\left(\mathrm{~s}, 2 \mathrm{H}, \mathrm{CH}_{2}-\mathrm{N} 3\right), 7.32-7.40\left(\mathrm{~m}, 2 \mathrm{H}, \mathrm{H}_{2,7}-\mathrm{Ar}\right)$, 7.44-7.55 ( $\mathrm{m}, 4 \mathrm{H}, \mathrm{H}_{1,3,6,8}-\mathrm{Ar}$ ), 7.86-7.90 (d def., $2 \mathrm{H}, \mathrm{H}_{4,5}-\mathrm{Ar}$ ), $9.08(\mathrm{~s}, 1 \mathrm{H}, \mathrm{NH})$. LC-MS: purity $95.11 \%, t_{\mathrm{R}}=5.46$, (ESI) $\mathrm{m} / \mathrm{z}$ : calculated for $\mathrm{C}_{18} \mathrm{H}_{14} \mathrm{~N}_{2} \mathrm{O}_{4}[\mathrm{M}+\mathrm{H}]^{+}$: 323.10 , found: 323.12 .

\subsubsection{Synthesis of methyl 2-(1'-(4-bromobutyl)-spiro(fluorene-} 9,5'-imidazolidin)-2', $\mathbf{4}^{\prime}$-dione-3'-yl)acetate (15)

Methyl 2-(spiro(fluorene-9,5'-imidazolidine)-2',4'-dione-3'-yl) acetate $14(0.025 \mathrm{~mol}, 8.05 \mathrm{~g})$, potassium carbonate $(10 \mathrm{~g})$, TEBA $(0.755 \mathrm{~g})$ in acetone $(50 \mathrm{ml})$ were stirred at room temperature for $30 \mathrm{~min}$. Then, a solution of 1,4-dibromobutane $(0.03 \mathrm{mmol}$, $6.42 \mathrm{~g})$ in acetone $(30 \mathrm{ml})$ was added and stirred at room temperature for $142 \mathrm{~h}$, according to a progress controlled by TLC (II). The inorganic precipitate was filtered off. The filtrate, after evaporation of solvents, was crystallized from ethanol to give white powder of 15. Yield 38\%; mp: $144-145{ }^{\circ} \mathrm{C}$; TLC: $R_{f}$ (II): $0.48 .{ }^{1} \mathrm{H}$ NMR (DMSO$\left.d_{6}, \mathrm{ppm}\right): \delta$ 1.06-1.15 (qu def, $2 \mathrm{H}, \mathrm{CH}_{2}-\mathrm{CH}_{2}-\mathrm{Br}$ ), 1.52-1.62 (qu, $\left.J=7.1 \mathrm{~Hz}, 2 \mathrm{H}, \mathrm{CH}_{2} \mathrm{CH}_{2}-\mathrm{N} 1\right), 2.89\left(\mathrm{t}, J=7.1 \mathrm{~Hz}, 2 \mathrm{H}, \mathrm{N} 1-\mathrm{CH}_{2}\right), 3.23$ $\left(\mathrm{t}, J=6.5 \mathrm{~Hz}, 2 \mathrm{H}, \mathrm{CH}_{2}-\mathrm{Br}\right), 3.73\left(\mathrm{~s}, 3 \mathrm{H}, \mathrm{OCH}_{3}\right), 4.40\left(\mathrm{~s}, 2 \mathrm{H}, \mathrm{CH}_{2}-\right.$ N3), 7.40-7.42 ( $\left.\mathrm{m}, 2 \mathrm{H}, \mathrm{H}_{2,7}-\mathrm{Ar}\right), 7.47-7.56\left(\mathrm{~m}, 4 \mathrm{H}, \mathrm{H}_{1,3,6,8}-\mathrm{Ar}\right)$, 7.93-7.95 ( $\left.\mathrm{d}_{\text {def }}, 2 \mathrm{H}, \mathrm{H}_{4,5}-\mathrm{Ar}\right)$. LC-MS: purity $95.23 \%, t_{\mathrm{R}}=7.60$, (ESI) $m / z$ : calculated for $\mathrm{C}_{22} \mathrm{H}_{21} \mathrm{BrN}_{2} \mathrm{O}_{4}[\mathrm{M}+\mathrm{H}]^{+}:$:458.32, found: 459.03 .

\subsubsection{General procedure for synthesis of arylpiperazine deriva- tives 8, 10-12}

Commercially available phenylpiperazine (3-5 mmol), $\mathrm{K}_{2} \mathrm{CO}_{3}$ $(1.2-2.0 \mathrm{~g})$ and acetone $(10-25 \mathrm{ml})$ were stirred for $30 \mathrm{~min}$. Then a solution of methyl 2-(1'-(4-bromobutyl)-spiro(fluorene-9,5'-imidazolidine)-2',4'-dione-3'-yl)acetate 15 (3-5 mmol, $1.37-2.29 \mathrm{~g}$ ) in acetone $(12-15 \mathrm{ml})$ was added. The mixture was maintained at reflux for $8 \mathrm{~h}$, left at room temperature for $15 \mathrm{~h}$. The precipitate was filtrated off. The filtrate was concentrated to constant weight. The crude residue was purified to give a precipitate of the final compound $(\mathbf{8}, \mathbf{1 0}-12)$.

4.1.4.1. Methyl 2-(1'-(4-(4-(2-furoyl)piperazin-1-yl)butyl)-spiro (fluorene-9,5'-imidazolidine)-2', $\mathbf{4}^{\prime}$-dione-3'-yl)acetate hydrochloride (8). 2-Furoylpiperazine (3 mmol, $0.54 \mathrm{~g}$ ), $\mathrm{K}_{2} \mathrm{CO}_{3}$ $(1.2 \mathrm{~g})$ in acetone $(10 \mathrm{ml})$ and methyl $2-\left(1^{\prime}-(4\right.$-bromobutyl)-spiro (fluorene-9,5'-imidazolidine)-2',4'-dione-3'-yl)acetate 15 (3 mmol, $1.37 \mathrm{~g})$ in acetone $(12 \mathrm{ml})$ were used. The crude residue was 
purified by column chromatography (methylene chloride-acetone, $10: 1, v / v)$. The purest product fractions were concentrated, dissolved in $\mathrm{EtOH}$ and saturated with gaseous $\mathrm{HCl}$. The precipitate was filtrated off and dried to give white powder of hydrochloride of 8. Yield 32\%; mp: $193-194{ }^{\circ} \mathrm{C}$; TLC: $R_{f}$ (III): $0.30 .{ }^{1} \mathrm{H}$ NMR (DMSO- $\left.d_{6}, \mathrm{ppm}\right): \delta$ 0.99-1.06 ( $\mathrm{m}, 2 \mathrm{H}, \mathrm{CH}_{2} \mathrm{CH}_{2}$-piperazine), 1.46 (br s, $2 \mathrm{H}, \mathrm{CH}_{2} \mathrm{CH}_{2}-\mathrm{N} 1$ ), 2.80 (br s, $2 \mathrm{H}, \mathrm{CH}_{2}$-piperazine), 2.92 ( $\mathrm{t}_{\mathrm{def}}$, $J=7.4 \mathrm{~Hz}, \quad 4 \mathrm{H}, \mathrm{H}_{2,6}$-piperazine), 3.29-3.43 (m, 6H, $\mathrm{CH}_{2}-\mathrm{N} 1$, $\mathrm{H}_{3,5}$-piperazine), $3.73\left(\mathrm{~s}, 3 \mathrm{H}, \mathrm{OCH}_{3}\right), 4.41\left(\mathrm{~s}, 2 \mathrm{H}, \mathrm{CH}_{2}-\mathrm{N} 3\right), 6.64$ ( $_{\text {def, }}$, $J=1.8 \mathrm{~Hz}, 1 \mathrm{H}, \mathrm{H}_{4}$-furan), 7.07 (d, $J=3.1 \mathrm{~Hz}, 1 \mathrm{H}, \mathrm{H}_{5}$-furan), 7.39-7.44 (m, 2H, $\left.\mathrm{H}_{2,7}-\mathrm{Ar}\right), 7.50-7.57$ ( $\mathrm{m}, 4 \mathrm{H}, \mathrm{H}_{1,3,6,8}-\mathrm{Ar}$ ), 7.85 (d, $J=1.0 \mathrm{~Hz}, 1 \mathrm{H}, \mathrm{H}_{3}$-furan), 7.95 (d, $J=7.4 \mathrm{~Hz}, 2 \mathrm{H}, \mathrm{H}_{4,5}-\mathrm{Ar}$ ), 10.31 (br s, $1 \mathrm{H}, \mathrm{NH}^{+}$). LC-MS: purity $96.16 \%, t_{\mathrm{R}}=4.56$, (ESI) $\mathrm{m} / \mathrm{z}$ : calculated for $\mathrm{C}_{31} \mathrm{H}_{33} \mathrm{~N}_{4} \mathrm{O}_{6}[\mathrm{M}+\mathrm{H}]^{+}$: 557.24, found: 557.38.

4.1.4.2. Methyl 2-(1'-(4-(4-(4-fluorophenyl)piperazin-1-yl)butyl)spiro(fluorene-9,5'-imidazolidin)-2', $\mathbf{4}^{\prime}$-dione-3'-yl)acetate (10). 4-(4-Fluorphenyl)piperazine ( $5 \mathrm{mmol}, 0.9 \mathrm{~g}), \mathrm{K}_{2} \mathrm{CO}_{3}(2.0 \mathrm{~g}$ ) in acetone $(15 \mathrm{ml})$ and methyl 2-(1'-(4-bromobutyl)-spiro(fluorene9,5'-imidazolidine)-2', $4^{\prime}$-dione-3'-yl)acetate 15 (5 mmol, $2.29 \mathrm{~g}$ ) in acetone $(15 \mathrm{ml})$ were used. The crude residue of $\mathbf{1 0}$ was purified by column chromatography. The individual fractions were eluted using the following pure solvents: methylene chloride and methanol. The obtained product fractions were concentrated. A sticky residue was obtained and crystallized from methanol to give white crystals of 10. Yield $25 \%$; mp: $142-143^{\circ} \mathrm{C}$; TLC: $R_{f}$ (III): $0.66 .{ }^{1} \mathrm{H}$ NMR (DMSO- $\left.d_{6}, \mathrm{ppm}\right): \delta 1.00$ (qu, $J=7.05 \mathrm{~Hz}, 2 \mathrm{H}, \mathrm{CH}_{2} \mathrm{CH}_{2}$-piperazine), $1.19\left(\mathrm{t}, J=6.2 \mathrm{~Hz}, 2 \mathrm{H}, \mathrm{CH}_{2} \mathrm{CH}_{2}-\mathrm{N} 1\right), 1.95(\mathrm{t}, J=7.2 \mathrm{~Hz}, 2 \mathrm{H}$, $\mathrm{CH}_{2}$-piperazine), $2.25\left(\mathrm{t}, J=5.0 \mathrm{~Hz}, 4 \mathrm{H}, \mathrm{H}_{2,6}\right.$-piperazine), 2.90 $2.94\left(\mathrm{~m}, 6 \mathrm{H}, \mathrm{CH}_{2}-\mathrm{N} 1\right.$ and $\mathrm{H}_{3,5}$-piperazine), $3.73\left(\mathrm{~s}, 3 \mathrm{H}, \mathrm{OCH}_{3}\right)$, $4.40\left(\mathrm{~s}, 2 \mathrm{H}, \mathrm{CH}_{2}-\mathrm{N} 3\right), 6.86-6.90\left(\mathrm{~m}, 2 \mathrm{H}, \mathrm{H}_{2,6}-\mathrm{PhPp}\right), 7.01(\mathrm{t}$, $J=6.1 \mathrm{~Hz}, 2 \mathrm{H}, \mathrm{H}_{3,5}-\mathrm{PhPp}$ ), 7.37-7.41 (m, 2H, $\left.\mathrm{H}_{2,7}-\mathrm{Ar}\right), 7.47-7.54$ (m, $4 \mathrm{H}, \mathrm{H}_{1,3,6,8}-\mathrm{Ar}$ ), 7.93 (d, $J=7.4 \mathrm{~Hz}, 2 \mathrm{H}, \mathrm{H}_{4,5}-\mathrm{Ar}$ ). LC-MS: purity $96.15 \%, t_{\mathrm{R}}=5.18$, (ESI) $\mathrm{m} / z$ : calculated for $\mathrm{C}_{32} \mathrm{H}_{33} \mathrm{FN}_{4} \mathrm{O}_{4}[\mathrm{M}+\mathrm{H}]^{+}$: 557.25, found: 557.44 .

4.1.4.3. Methyl 2-(1'-(4-(4-phenylpiperazin-1-yl)butyl)-spiro (fluorene-9,5' -imidazolidine)-2', $4^{\prime}$-dione-3'-yl)acetate (11). $\mathrm{N}$-Phenylpiperazine ( $4 \mathrm{mmol}, 0.64 \mathrm{~g}), \mathrm{K}_{2} \mathrm{CO}_{3}(1.6 \mathrm{~g})$ in acetone $(25 \mathrm{ml})$ and methyl 2-(1'-(4-bromobutyl)-spiro(fluorene-9,5'-imidazolidine)-2',4'-dione-3'-yl)acetate $\mathbf{1 5}$ (4 mmol, $1.83 \mathrm{~g}$ ) in acetone $(12 \mathrm{ml})$ were used. The crude residue was crystallized with methanol to give a white powder of 11. Yield $37 \%$; mp: $117-118{ }^{\circ} \mathrm{C}$; TLC: $R_{f}$ (III): 0.69. ${ }^{1} \mathrm{H}$ NMR (DMSO- $\left.d_{6}, \mathrm{ppm}\right): \delta 1.00\left(\mathrm{t}, J=7.2 \mathrm{~Hz}, 2 \mathrm{H}, \mathrm{CH}_{2^{-}}\right.$ $\mathrm{CH}_{2}$-piperazine), $1.17-1.22\left(\mathrm{~m}, 2 \mathrm{H}, \mathrm{CH}_{2} \mathrm{CH}_{2}-\mathrm{N} 1\right), 1.96(\mathrm{t}, \mathrm{J}=2 \mathrm{H}$, $\mathrm{CH}_{2}$-piperazine), $2.26\left(\mathrm{t}, \mathrm{J}=1.8 \mathrm{~Hz}, 4 \mathrm{H}, \mathrm{H}_{2,6}\right.$-piperazine), 2.89 $2.97\left(\mathrm{~m}, 6 \mathrm{H}, \mathrm{CH}_{2}-\mathrm{N} 1, \mathrm{H}_{3,5}\right.$-piperazine), $3.31\left(\mathrm{~s}, 3 \mathrm{H}, \mathrm{OCH}_{3}\right), 4.40(\mathrm{~s}$, $\left.2 \mathrm{H}, \mathrm{CH}_{2}-\mathrm{N} 3\right), 6.74\left(\mathrm{t}, J=5.6 \mathrm{~Hz}, 1 \mathrm{H}, \mathrm{H}_{4}-\mathrm{PhPp}\right), 6.87$ (d, $2 \mathrm{H}$, $\left.J=4.6 \mathrm{~Hz}, \mathrm{H}_{2,6}-\mathrm{PhPp}\right) .7 .18$ (t, $\left.J=5.6 \mathrm{~Hz}, 2 \mathrm{H}, \mathrm{H}_{3,5} \mathrm{PhPp}\right), 7.39-7.42$ (m, 2H, $\left.\mathrm{H}_{2,7}-\mathrm{Ar}\right), 7.47-7.54\left(\mathrm{~m}, 4 \mathrm{H}, \mathrm{H}_{1,3,6,8}-\mathrm{Ar}\right), 7.93$ (d, $2 \mathrm{H}$, $J=7.7 \mathrm{~Hz}, \mathrm{H}_{4,5}-\mathrm{Ar}$ ). LC-MS: purity $95.18 \%, t_{\mathrm{R}}=5.32$, (ESI) $\mathrm{m} / \mathrm{z}$ : calculated for $\mathrm{C}_{32} \mathrm{H}_{34} \mathrm{~N}_{4} \mathrm{O}_{4}[\mathrm{M}+\mathrm{H}]^{+}:$539.26, found: 539.43 .

4.1.4.4. Methyl 2-(1'-(4-(4-(2-fluorophenyl)piperazin-1-yl)butyl)spiro(fluorene-9,5'-imidazolidine)-2' $\mathbf{4}^{\prime}$-dione-3'-yl)acetate (12). 4-(2-Fluorphenyl)piperazine ( $4 \mathrm{mmol}, 0.72 \mathrm{~g}), \mathrm{K}_{2} \mathrm{CO}_{3}(1.6 \mathrm{~g})$ in acetone $(25 \mathrm{ml})$ and methyl 2-(1'-(4-bromobutyl)-spiro(fluorene9,5'-imidazolidine)-2',4'-dione-3'-yl)acetate 15 (4 mmol, $1.83 \mathrm{~g})$ in acetone $(12 \mathrm{ml})$ were used. The crude residue was crystallized with methanol to give white powder of 12. Yield $82 \%$; mp $99-101^{\circ} \mathrm{C}$; TLC: $R_{f}$ (III): $0.65{ }^{1} \mathrm{H}$ NMR (DMSO- $\left.d_{6}, \mathrm{ppm}\right): \delta 1.00(\mathrm{t}, J=6.4 \mathrm{~Hz}$, $\left.2 \mathrm{H}, \mathrm{CH}_{2} \mathrm{CH}_{2}-\mathrm{Pp}\right), 1.19\left(\mathrm{t}, J=6.2 \mathrm{~Hz}, 2 \mathrm{H}, \mathrm{CH}_{2} \mathrm{CH}_{2}-\mathrm{N} 1\right), 1.97$ (t, $J=7.2 \mathrm{~Hz}, 2 \mathrm{H}, \mathrm{CH}_{2}-\mathrm{Pp}$ ), 2.28 (br s, $4 \mathrm{H}, \mathrm{H}_{2,6}-\mathrm{Pp}$ ), 2.83-2.92 (m, $6 \mathrm{H}$, $\left.\mathrm{CH}_{2}-\mathrm{N} 1, \mathrm{H}_{3,5}-\mathrm{Pp}\right), 3.73$ (s, 3H, OCH $\left.{ }_{3}\right), 4.40$ (s, 2H, $\left.\mathrm{CH}_{2}-\mathrm{N} 3\right), 6.94-$ 6.97 ( $\mathrm{m}, 2 \mathrm{H}, \mathrm{H}_{4,6}-\mathrm{PhPp}$ ), 7.06-7.12 ( $\left.\mathrm{m}, 2 \mathrm{H}, \mathrm{H}_{3,5} \mathrm{PhPp}\right), 7.37-7.42$ (m, $2 \mathrm{H}, \mathrm{H}_{2,7}-\mathrm{Ar}$ ), 7.47-7.55 (m, $4 \mathrm{H}, \mathrm{H}_{1,3,6,8}-\mathrm{Ar}$ ), 7.94 (d, $J=3.8 \mathrm{~Hz}$,
$2 \mathrm{H}, \mathrm{H}_{4,5}-\mathrm{Ar}$ ). LC-MS: purity $95.17 \%, t_{\mathrm{R}}=5.34$, (ESI) $\mathrm{m} / z$ : calculated for $\mathrm{C}_{32} \mathrm{H}_{33} \mathrm{FN}_{4} \mathrm{O}_{4}[\mathrm{M}+\mathrm{H}]^{+}:$557.25, found: 557.44 .

4.1.4.5. Synthesis of 2-(1'-(4-(4-(2-furoyl)piperazin-1-yl)butyl)spiro(fluorene-9,5'-imidazolidine)-2', $4^{\prime}$-dione-3'-yl)acetic acid (9). Methyl 2-(1'-(4-(4-(2-furoyl)piperazin-1-yl)butyl)-spiro (fluorene-9,5'-imidazolidine)-2',4'-dione-3'-yl)acetate $8 \quad(0.54$ mmol, $0.3 \mathrm{~g}), 50 \% \mathrm{EtOH}(4 \mathrm{ml}), \mathrm{KOH}(0.2 \mathrm{~g})$ was stirred for $2 \mathrm{~h}$. Sticky substance was obtained and left in lower temperature to crystallize. The precipitate was filtrated off and dried to give white powder of 9 . Yield $80 \%$; mp: $182-183^{\circ} \mathrm{C}$; TLC: $R_{f}$ (IV): 0.15 . ${ }^{1} \mathrm{H}$ NMR (DMSO- $\left.d_{6}, \mathrm{ppm}\right): \delta 0.99\left(\mathrm{t}, J=7.7 \mathrm{~Hz}, 2 \mathrm{H}, \mathrm{CH}_{2}\right.$-piperazine), 1.38 (br s, $2 \mathrm{H}, \mathrm{CH}_{2} \mathrm{CH}_{2}-\mathrm{N} 1$ ), $2.91\left(\mathrm{t}, J=7.2 \mathrm{~Hz}, 6 \mathrm{H}, \mathrm{CH}_{2}\right.$-pierazine and $\mathrm{H}_{2,6}$-piperazine), 3.32-3.43 (m, 6H, $\mathrm{CH}_{2}-\mathrm{N} 1$ and $\mathrm{H}_{3,5}$-piperazine), 4.27 (s, $2 \mathrm{H}, \mathrm{CH}_{2}-\mathrm{N} 3$ ), $6.62-6.64$ (dd, $J=5.4 \mathrm{~Hz}$, $1 \mathrm{H}, \mathrm{H}_{4}$-furan), 7.04 (d, J=3.3 Hz, $1 \mathrm{H}, \mathrm{H}_{5}$-furan), $7.38-7.42$ (m, 2H, $\mathrm{H}_{2,7}-\mathrm{Ar}$ ), 7.49-7.56 ( $\mathrm{m}, 4 \mathrm{H}, \mathrm{H}_{1,3,6,8}-\mathrm{Ar}$ ), 7.85 (d, J = $0.8 \mathrm{~Hz}$, $1 \mathrm{H}, \mathrm{H}_{3}$-furan), 7.95 (d, $J=6.4 \mathrm{~Hz}, 2 \mathrm{H}, \mathrm{H}_{4,5}-\mathrm{Ar}$ ). LC-MS: purity $98.11 \%, t_{\mathrm{R}}=3.98$, (ESI) $\mathrm{m} / \mathrm{z}$ : calculated for $\mathrm{C}_{30} \mathrm{H}_{30} \mathrm{~N}_{4} \mathrm{O}_{6}[\mathrm{M}+\mathrm{H}]^{+}$: 543.22, found: 543.42 .

\subsection{X-ray crystal structure analysis}

Crystals of both compounds were obtained at room temperature from a solution of propan-2-ol and water by slow evaporation of the solvent. Colourless crystals appeared within three months. Data for single crystals were collected using the Oxford Diffraction SuperNova four circle diffractometer, equipped with the Mo $(0.71069 \AA) \mathrm{K} \alpha$ radiation source, graphite monochromator. Positions of all non-hydrogen atoms were determined by direct methods using SIR-97. ${ }^{20}$ All non-hydrogen atoms were refined anisotropically using weighted full-matrix least-squares on $\mathrm{F}^{2}$. Refinement and further calculations were carried out using SHELXL-97. ${ }^{21}$ ORTEP $^{22}$ and MERCURY ${ }^{23}$ programs were used for molecular graphics.

8: $\left[\left(\mathrm{C}_{31} \mathrm{H}_{33} \mathrm{~N}_{4} \mathrm{O}_{6}\right)^{+} \mathrm{Cl}^{-}\right] \cdot \mathrm{H}_{2} \mathrm{O}, \quad \mathrm{Mr}=611.08, \quad$ crystal size $0.46 \times 0.43 \times 0.19 \mathrm{~mm}^{3}$, monoclinic, space group $\mathrm{P} 2 / \mathrm{n}$, $a=11.891(5) \AA, \quad b=13.382(5) \AA, \quad c=18.980(5) \AA, \quad \beta=100.512(5)^{\circ}$, $V=2970(2) \AA^{3}, Z=4, T=293(2) \mathrm{K}, 40796$ reflections collected, 7210 independent reflections $(R(\mathrm{int})=0.0265), \quad R_{1}=0.0734$, $w R_{2}=0.2067(I>2 \operatorname{sigma}(I)), R_{1}=0.0986, w R_{2}=0.2292$ (all data).

11: $\mathrm{C}_{32} \mathrm{H}_{34} \mathrm{~N}_{4} \mathrm{O}_{4}, \quad \mathrm{Mr}=538.63$, crystal size $0.46 \times 0.25 \times$ $0.14 \mathrm{~mm}^{3}$, monoclinic, space group $\mathrm{P} 2{ }_{1} / \mathrm{c}, \quad a=18.7592(5) \AA$, $b=11.2153(3) \AA, c=13.8436(4) \AA, \beta=107.031(3)^{\circ}, V=2784.8(1) \AA^{3}$, $Z=4, T=120(2) \mathrm{K}, 39045$ reflections collected, 6661 independent reflections $(R(\mathrm{int})=0.0560), R_{1}=0.0483, w R_{2}=0.1155(I>2$ sigma $(I)), R_{1}=0.0667, w R_{2}=0.1279$ (all data).

CCDC 1444020 and 1444021 contain the supplementary crystallographic data for compounds $\mathbf{1 1}$ and $\mathbf{8}$, respectively. These data can be obtained free of charge from The Cambridge Crystallographic Data Centre via www.ccdc.cam.ac.uk/data_request/cif.

\subsection{Biological assays}

\subsubsection{Cell lines}

The L5178 mouse T-cell lymphoma cells (PAR) (ECACC Cat. No. 87111908 , obtained from FDA, Silver Spring, MD, USA) were transfected with pHa MDR1/A retrovirus, as previously described by Cornwell et al. ${ }^{18}$ ABCB1-expressing cell line L5178Y (MDR) was selected by culturing the infected cells with colchicine. L5178 (parent) mouse T-cell lymphoma cells and the L5178Y human $A B C B 1$-transfected subline were cultured in McCoy's 5A medium supplemented with $10 \%$ heat inactivated horse serum, $200 \mathrm{mM}$ L-glutamine, and penicillin-streptomycin mixture in $100 \mathrm{U} / \mathrm{l}$ and $10 \mathrm{mg} / \mathrm{l}$ concentration, respectively. 


\subsubsection{Assay for cytotoxic effect}

The effects of increasing concentrations of the drugs alone on cell growth were tested in 96-well flat-bottomed microtiter plates. The compounds were diluted in a volume of $100 \mu \mathrm{l}$ medium. Then, $2 \times 10^{4}$ L5178 mouse T-lymphoma cells (PAR or MDR) in $100 \mu \mathrm{l}$ of medium, respectively, were added to each well, with the exception of the medium control wells. The culture plates were further incubated at $37^{\circ} \mathrm{C}$ for $24 \mathrm{~h}$; at the end of the incubation period, $20 \mu \mathrm{l}$ of MTT solution (from a $5 \mathrm{mg} / \mathrm{ml}$ stock) was added to each well. After incubation at $37^{\circ} \mathrm{C}$ for $4 \mathrm{~h}, 100 \mu \mathrm{l}$ of SDS solution (10\% in $0.01 \mathrm{M}$ $\mathrm{HCI}$ ) was added to each well and the plates were further incubated overnight at $37^{\circ} \mathrm{C}$ overnight. The cell growth was determined by measuring the OD at $540 \mathrm{~nm}$ (ref. $630 \mathrm{~nm}$ ) with Multiscan EX ELISA reader (Thermo Labsystems, Cheshire, WA, USA).

\subsubsection{Fluorescence uptake assay}

The cell number of L5178 MDR and L5178Y PAR cell lines was adjusted to $2 \times 10^{6}$ cells $/ \mathrm{ml}$, re-suspended in serum-free McCoy's $5 \mathrm{~A}$ medium and distributed in $0.5 \mathrm{ml}$ aliquots into Eppendorf centrifuge tubes. The tested compounds were added at a final concentration of 2 and $20 \mu \mathrm{M}$, and the samples were incubated for $10 \mathrm{~min}$ at room temperature. Verapamil was applied as positive control at $20 \mu \mathrm{M}$. DMSO was added to the negative control tubes at the same volume that had been used for the tested compounds. No activity of DMSO was observed. Next, $10 \mu \mathrm{l}(5.2 \mu \mathrm{M}$ final concentration) of the fluorochrome and $A B C B 1$ substrate rhodamine 123 was added to the samples and the cells were incubated for a further $20 \mathrm{~min}$ at $37^{\circ} \mathrm{C}$, washed twice and re-suspended in $0.5 \mathrm{ml}$ PBS for analysis. The fluorescence of the cell population was measured with a PartecCyFlow ${ }^{\circledR}$ flow cytometer (Partec, Münster, Germany). The percentage of mean fluorescence intensity was calculated for the treated MDR cells as compared with the untreated cells. A fluorescence activity ratio (FAR) was calculated based on the following equation on the basis of the measured fluorescence values:

$\mathrm{FAR}=\frac{\mathrm{MDR}_{\text {treated }} / \mathrm{MDR}_{\text {control }}}{\text { parental }_{\text {treated }} / \text { parental }_{\text {control }}}$

\section{Acknowledgments}

Authors thank to students: Justyna Bryła (Jagiellonian University, Medical College, Poland), Ana Rita Borba and Catia Seabra (University Porto, Portugal) for their participation in the chemical synthesis works. The equipment used for X-ray data collection was purchased thanks to the financial support of the European Regional Development Fund in the framework of the Polish Innova- tion Economy Operational Program (contract no. POIG.02.01.0012-023/08). The work was partly supported by Polish programs of statutory research K/ZDS/005593 and K/ZDS/004689 (Jagiellonian University-Medical College) and by Pedagogical University of Cracow.

\section{Supplementary data}

Supplementary data associated with this article can be found, in the online version, at http://dx.doi.org/10.1016/j.bmc.2016.04.055.

\section{References and notes}

1. Nobili, S.; Landini, I.; Giglioni, B.; Mini, E. Curr. Drugs Targets 2006, 7, 861.

2. Stavrovskaya, A. A. Stromskaya, T. P. Biochemistry (Moscow) 2008, 73, 592.

3. Teodori, E.; Dei, S.; Scapecchi, S.; Gualtieri, F. Il Farmaco 2002, 57, 385.

4. Ernst, R.; Kueppers, P.; Stindt, J.; Kuchler, K.; Schmitt, L. FEBS J. 2010, 277, 540.

5. Hall, M. D.; Handley, M. D.; Gottesman, M. M. Trends Pharmacol. Sci. 2009, 30, 546.

6. Choi, Ch.-H. Cancer Cell Int. 2005, 5, 30

7. Zdrazil, B.; Kaiser, D.; Kopp, S.; Chiba, P.; Ecker, G. F. QSAR Comb. Sci. 2007, 26, 669.

8. Weyand, S.; Shimamura, T.; Yajima, S.; Suzuki, S.; Mirza, O.; Krusong, K.; Carpenter, E. P.; Rutheford, N. G.; Hadden, J. M.; O’Reilly, J.; Ma, P.; Saidijam, M.; Patching, S. G.; Hope, R. J.; Norbertczak, H. T.; Roach, P. C. J.; Iwata, S.; Henderson, P. J. F.; Cameron, A. D. Science 2008, 332, 709.

9. Weyand, S.; Shimamura, T.; Beckstein, O.; Sansom, M. S. P.; Iwata, S.; Henderson, P. J. F.; Cameron, A. D. J. Synchrotron Rad. 2011, 18, 20.

10. Mudit, M.; Khanfar, M.: Muralidharan, A.: Thomas, S.; Shah, G. V.: van Soest, R W.; El Sayed, K. A. Bioorg. Med. Chem. 2009, 15, 1731. Erratum in: Bioorg Med Chem. 2009, 15, 3216.

11. Spengler, G.; Evaristo, M.; Handzlik, J.; Serly, J.; Molnár, J.; Viveiros, M.; KiećKononowicz, K.; Amaral, L. Anticancer Res. 2010, 30, 4867.

12. Spengler, G.; Handzlik, J.; Ocsovszki, I.; Viveiros, M.; Kieć-Kononowicz, K. Molnar, J.; Amaral, L. Anticancer Res. 2011, 31, 3285.

13. Martins, A.; Dymek, A.; Handzlik, J.; Spengler, G.; Armada, A.; Molnar, J.; KiécKononowicz, K.; Amaral, L. In Vivo 2012, 26, 293.

14. Handzlik, J.; Spengler, G.; Mastek, B.; Dela, A.; Molnar, J.; Amaral, L.; Kieć Kononowicz, K. Acta Polon. Pharm.-Drug Res. 2012, 69, 149.

15. Handzlik, J.; Bajda, M.; Zygmunt, M.; Maciąg, D.; Dybała, M.; Bednarski, M.; Filipek, B.; Malawska, B.; Kieć-Kononowicz, K. Bioorg. Med. Chem. 2012, 20 , 2290.

16. Handzlik, J.; Szymańska, E.; Chevalier, J.; Otrebska, E.; Kieć-Kononowicz, K. Pagès, S.; Alibert, J. M. Eur. J. Med. Chem. 2011, 46, 5807.

17. Handzlik, J.; Szymańska, E.; Nędza, K.; Kubacka, M.; Siwek, A.; Mogilski, S.; Handzlik, J.; Filipek, B.; Kié́-Kononowicz, K. Bioorg. Med. Chem. 2011, 19, 1349.

18. Cornwell, M. M.; Pastan, I.; Gottesman, M. M. J. Biol. Chem. 1987, 262, 2166.

19. Spengler, G.; Viveiros, M.; Martins, M.; Rodrigues, L.; Molnar, J.; Couto, I.; Amaral, L. Anticancer Res. 2009, 29, 2173.

20. Altomare, A.; Burla, M. C.; Camalli, M.: Cascarano, G. L.; Giacovazzo, C.; Guagliardi, A.; Moliterni, A. G. G.; Polidori, G.; Spagna, R. J. Appl. Cryst. 1999, 32, 115.

21. Sheldrick, G. M. Acta Cryst. 2008, A64, 112.

22. Farrugia, L. J. J. Appl. Cryst. 2012, 45, 849.

23. Macrae, C. F.; Edgington, P. R.; McCabe, P.; Pidcock, E.; Shields, G. P.; Taylor, R.; Towler, M.; van de Streek, J. J. Appl. Cryst. 2006, 39, 453. 